Ing Lwan Taga-Tan, Patricia Tjiook-Liem, Yap Kioe Bing (eds), Een Foto Vertelt: Vijftig familieverhalen van Chinezen uit Indonesië. Den Haag: Stichting Tong Tong, 2019, 191 pp. ISBN: 9789O78847106, price: EUR 25 (paperback).

The richly illustrated book Een Foto Vertelt (A Photograph Narrates) was recently published by the Chinese Indonesian Heritage Center (CIHC). This foundation aims to preserve the heritage of Chinese people who lived in Indonesia and moved to the Netherlands. Since its founding in 2011, the CIHC has promoted its mission in several ways, including by publishing on their website stories by various community members. Fifty of those online stories have now been bundled into this visually attractive publication. Each contribution takes either one or two photographs, a document, or an object as a starting point. These various objects serve as vehicles to tell a wide range of stories, some utterly personal, some more descriptive. However, what the contributions have in common is firstly that they are the outcome of a shared Chinese Indonesian heritage. Secondly, they are dealing with issues around belonging and home-making. Thirdly, they are stories showing the community's resilience.

The book is structured around two time periods: 1894 to 1945 , and 1945 up to the present. The contributions in the first part are often stories written by (grand)children, about working and living in pre-war Indonesia or about family. These contributions are often descriptive, and personal experiences or additions are less predominant. Sioe Yao Kan for example, who contributed six stories to the volume, explains the interconnectedness between the Han, Kan, and Tan families through marriage and adoption. The narrative is based on two studio portraits around 1894 and 1910 from his family archive. Another striking family story is told by Ing Han Go, whose grandparents were a mixed ChineseIndonesian and Dutch couple who dealt with rejection. Ing Han Go tells this rather difficult story with a photograph showing his grandparents, mother, and aunt as a happy family. Other stories feature daily life in pre-war Indonesia, including contributions about work life and schooling systems, such as running a batik company (Kwee Hin Goan) or a jeweller's shop (Tan Tiong Boen), and the education at the sтоviт (Swanny Thee). The importance of the Chinese Indonesian association Chung Hwa Hui in both Indonesia (Liem Hoo Soei) and among students in the Netherlands (Yap Kioe Bing) are other examples of the rich variety of stories. One could say that the contributions in the first part of the book aim to show the importance of Chinese heritage in Indonesia, which is of great importance to the Chinese Indonesian readership in the Netherlands who identify with these histories. Accounts in the second part show how this past is linked to the present. 
The stories after 1945 are mostly first hand experiences of the writers themselves. Migration is a shared theme. Chinese Indonesians migrated, just after World War II, to study in the Netherlands, or to escape the Indonesian war of independence. Other authors left Indonesia after the attempted 1965 coup. These are stories about building a new life and home-making in the Netherlands. For example, Patricia Tjiook-Liem explains the importance of bringing a portrait of their Indonesian personnel. Thus, a photograph taken in Indonesia is important in the process of home-making elsewhere. Dhian Siang Lie discusses a snapshot in which he together with his brother and parents are photographed just after they have been naturalized as Dutch. The posing of the family with a Dutch flag strongly underlines this new sense of belonging. The contributions in this second part show how resilient the community is, despite the hardships of World War II and anti-Chinese-Indonesian racism. Een Foto Vertelt shows how important Chinese Indonesian heritage and culture is to the CIHC and its supporters. Even though this volume is first and foremost written by and for this particular readership, the content should interest a larger audience.

The book lays out what personal photographs can do when they are published outside the context of the family album or archive. The well-chosen book title emphasizes this active role even more than the original website heading, "a photograph with story", which is more passive in nature. A single item is used to tell bigger stories of heritage, belonging, and identity. Photographs, often depicting happy moments, might recall different memories that are less happy, or might be about struggle. The vast majority of the published photographs, documents, and objects have travelled from Indonesia to the Netherlands. These precious examples from the personal archives are still in motion; by publishing them online and book form, they move from the private or domestic into the public sphere. One could say that the examples published in Een Foto Vertelt are a means of keeping in touch with the Chinese Indonesian community in the Netherlands across geographical distances and time.

The lion's share of the authors tell their stories on the basis of photographs. As shown in the publication, they are tactile and multi-layered objects in the sense that they are records of daily live to which new significance is added over time. Unfortunately, the majority of the photographs are published as cropped images - they have lost the layer of captions and annotations, which are voices that also add to the multi-layeredness of their stories. This could be resolved easily in the online stories and a possible second edition of the book.

\section{Liesbeth Ouwehand}

National Museum of World Cultures, Leiden, the Netherlands

liesbeth.ouwehand@wereldculturen.nl 